\title{
МЕДІАКУЛЬТУРА
}

Visn. Lviv. Univ., Ser. Zhurn. 2021: 50; 128-136 • DOI: http://dx.doi.org/10.30970/vjo.2021.50.11103

УДК 81’23:159.946.3]:316.772

\section{SEMANTIC OF QUIET AND SILENCE BASED ON POLISH HUMAN SCIENCE}

\author{
Grażyna Filip \\ Rzeszów University, \\ al. Rejtana 16c, Rzeszów, Poland \\ e-mail: grazka.filip.@gmail.com \\ https://orcid.org/0000-0002-2564-1205
}

The article is an introduction to an individual research subject called The Communicational Potential of Silence, planned - and partially already realised since 2020 - as a cycle of publications based on diversified example material. In print are already two texts: G. Filip, The Communicational Potential of Silence. Film Reviews (University of Rzeszów Publishing House) and G. Filip, The Communicational Potential of Silence. Automotive Brand Press Maria CurieSkłodowska University of Lublin Publishing House). The presented here English-language article serves for popularization Poland-wide and local (University of Rzeszów) research in the field communications.

Key words: social communication, pragmalinguistic, semantic of quiet and silence, film reviews, automotive brand press.

The direct impulse for starting the subject was the book of Norwegian philosopher Erling Kagge called Silence. The Story About Why We Lost the Ability to Stay in Silence and How to Get it Back ${ }^{1}$, containing assumptions which are important from communicational point of view:

1. Silence - understood as not using words, not an absolute silence - it shall speak.

2. Silence should be properly talked with and listened to, because words limit human's experiences and can make the mood worse.

3. Silence can be boring, hard, it can exclude, trouble, scare, sometimes it is a sign of loneliness.

4. We live in the times of noise, silence got under pressure.

5. One should not wait for an absolute silence, a unique, niche kind should be created for oneself.

6. Silence can be friendly and safe.

\footnotetext{
1 Kagge, E. (2017), Cisza. Opowieść o tym, dlaczego straciliśmy umiejętność przebywania w ciszy i jak ją odzyskać, $127 \mathrm{p}$.

(C) Філіп Г., 2021
} 
7. It enriches, it is a high quality, exclusive and luxurious thing (the features presented in this point became a starting point for silence's communicational potential analysis on the automotive branding material).

8. Silence can also be a communication tool, while the words can break as well communication and the $\operatorname{mood}^{2}$. The cited statements are not direct quotes and are not a continual text, but they were chosen from pages given in the bibliographic footnote. The philosophic aspects of silence are fixed in the asset of language. The presented in PWN Polish Language Dictionary lexical definition of this term and it's synonyms are direct or implied extensions to most of the above cited statements from Erling Kagge's book, so the silence is:

1) «a state in which no sound appear»,

2) «non-windy weather»,

3) «calm in some place»,

4) «spiritual balance»,

5) «lack of reaction to something»,

6) «lack of information about someone»,

7) «lack of radio connection».

Synonyms:

- silence (lack of sounds) solitude, meekness;

- silence (of monastic life) calm;

- silence (in someone's soul) $\mathrm{calm}^{3}$.

On the basis of Polish human science, including linguistics, the problematic of silence and muteness has its own subject literature, classic representation of which are two, edited by Kwiryna Handke, monographs: Semantics of Muteness. Collection of Studies ${ }^{4}$ and Semantics of Muteness $2^{5}$. Both volumes contain material from scientific conferences «Semantics of Muteness» organised by Slavistics Institute of PAN and Academy of Music in Warsaw, in November 1998 and 2001. This multi-author monographs are build of from one side theoretical and philosophical studies concerning the concept and act of muteness and antinomy speech - muteness. The other side though are the analysis of this concepts in different disciplines of literature and arts, above all in music, painting and film.

In the foreword to published in 1999 volume Kwiryna Handke signalises the pioneer character of the monograph edited by her, writing that the problematic of silence and muteness was previously a subject of interest only for philosophers and sociologists. For main research problem she chooses the Norwid's «meaningful silence» ${ }^{6}$. In the published in this collection article Jerzy Faryno pays attention to the semantic duality of contrasting pair of verbs speak and be silent: «On this basic duality to speak (it's impossible to communicate anything without using verbal language) based are two important, previously paradox for sure, metaphors: to speak remaining silent, which is to communicate a specific content without using voice (to speak by eyes, gestures) and remain silent while speaking which is to communicate verbally without communicating a specific content (to skip something,

\footnotetext{
2 Kagge, E. (2017), Cisza. Opowieść o tym, dlaczego straciliśmy umiejętność przebywania w ciszy i jak ją odzyskać, p. 17-86.

3 URL: https://sjp.pwn.pl, dostęp 25 stycznia 2020 r.

4 Handke, K. (1999), Ed. Semantyka milczenia. Zbiór studiów, 254 p.

5 Handke, K. (2002), Ed. Semantyka milczenia 2, 229 p.

6 Handke, K. (1999), Ed. Semantyka milczenia, Zbiór studiów, p. 7.
} 
leave unsaid)»?. The author formulates a definition important for communicational analyses: «As a communicational unit (made of silence/muteness) silence is always addressed to someone and one remains silent about something to someone» ${ }^{8}$.

Anna Pietura, in turn, in the chapter called Silence in Andrzej Wajda's Movies presents a quote from Roman Ingarden's A Couple of Remarks on Film Art: «A film spectacle is an artistic creation standing on the crossing of many arts, which cooperates with each other, combine into quite peculiar creations» ${ }^{9}$. According to the author film is a synthesis of artistic silence because of skilful operating with picture, music, motion and light, which are the elements of film language. Concealment is what she considers one of the most valued dramatic techniques in film: «In case of silence in film it is even hard to speak about silence in the traditional literature meaning of this word. This kind of silence in movie would be an empty, soundless screen, this is though the only case in which a person is not reached by any film technique perception phenomenon. This is why a silence of this kind is impossible in film. It can't exist, because it would be just a break in the film screening, a breakage of its structure. If silence appears in film in the traditional meaning, it stays on screen for only two, three seconds. It is this way because film in its essence is a non-interrupted cycle of impressions and lack of word or music is compensated by the speech of picture and motion, or reverse ${ }^{10}$. Individualised specialist definition of film silence has an influence on precising this concept in film reviews as verbal interpretations of films with perlocutive function convincing or disheartening the spectator.

The important theoretical basis of the project mentioned in the introduction is Jacek Juliusz Jadacki's publication called Pragmatic Functions of Muteness issued in the second volume of Semantics of Muteness ${ }^{11}$. According to the author, ritualised muteness and understatements (presuppositions or implications), so essences arising from some text do not have semantic functions, but they themselves are results of semantic functions played by a defined context. Jadacki therefore distinguishes impulsive muteness (for which he uses an Old-Polish name milczawa) from intentional: «Dissembling - so potentialised muteness is a muteness with skipping some information, but without an effective understatement. An evidence of it is among others lack of simple present tense for verb to dissemble (there is only gnomic): someone dissembles something - it is not like someone is dissembling something at the moment, but as he did dissembled something $\rangle^{12}$. In case of e.g. explicitly formulated questions - one the one who asks requires comprehensive explanation - dissembles the one, who gives non-comprehensive or even equivocal answer. As an effect, the pragmatic function of dissembling is being a sign of some permanent or temporary mental states. The pragmatic functions of staying silent are though an emphasis (in between or at the beginning of a statement) of this, what was already said or what is going to be said or of exhaustion of the topic (in the end of the statement). The first one in Jadacki's opinion is supposed to draw attention or raise tension, the second is a pragmatic substitute of statement: «I finished». Muteness as such is according to the author an effective intentional

\footnotetext{
7 Faryno, J., Skąd wiesz, kiedy milczę?, Semantyka milczenia, Zbiór studiów, Ed. K. Handke, p. 35.

8 Faryno, J., Skąd wiesz, kiedy milczę?, Semantyka milczenia, Zbiór studiów, Ed. K. Handke, p. 39.

9 Pietura, A. (1999), Cisza w filmach Andrzeja Wajdy, Semantyka milczenia, Zbiór studiów, p. 203.

${ }^{10}$ Pietura, A. (1999), Cisza w filmach Andrzeja Wajdy, Semantyka milczenia, Zbiór studiów, p. 222.

${ }_{11}$ Jadacki, J. J. (2002), Pragmatyczne funkcje milczenia. Semantyka milczenia 2. Ed. K. Handke, p. 11-17.

12 Jadacki, J. J. (2002), Pragmatyczne funkcje milczenia. Semantyka milczenia 2. Ed. K. Handke, p. 13.
} 
muteness. Pragmatic functions of such defined term become relative for expected reaction for some stimulus, especially someone's action and it can be:

1. The reverse of expected reaction - its motif can be indulgence or kindness or envy or jealousy.

2. Refusal (or at least not willing to reveal reaction - or the fact having the expected reaction - an obligation to keep secret, fear of undesired results of revealing something, shame (confusion), presumptive misunderstanding.

3. Indifference - motif of it is disrespect, ignoring by muteness ${ }^{13}$.

Muteness as a Radio Sign is a title of next chapter fro presented volume. Deliberations of Marian Jurkowski pertain to the specific of muteness (silence) as a radio sign. Silence is an element that confronts polyphony, so all the radio sounds, while muteness is in this case a pause, confronting only the radio verbal subcode. The author claims, that in a consciously formulated radio silence or muteness we «watch» the world presented only by «mind's eyes» and this world can be interpreted in infinitely many ways. Exactly in it Jurkowski sees the specific and strength of muteness as a radio sign ${ }^{14}$.

About the role of muteness in actor's interpretation, also basing on many years of job experience, wrote the representative of Polish classic film school - Aleksandra Górska: "Actor is above all the one, who acts (operates). Of course, in most cases he speaks while acting, but often he acts in silence; and it is not only in silent roles, in which he must appear without a word, but also, when by action he can say more than by a word, or when he act against the word: if for example the expressed words contradict the real intentions of the played character. [...] Muteness in actor's action is either a limitation of his possibilities or motionlessness; both options have potential of huge expression $\rangle^{15}$.

Kwiryna Handke analysed two-layered structure of social communication. According to the researcher it consists of two following layers: 1) the surface, which is a limited verbal communicate (which is on some topic... about some object...); 2) deep, which is, also limited, but incomparably wider muteness (which is on some topic... about some object...); muteness equal to understatement or dissembling a part of communicated statement in the expressed text of surface layer. The author considers a communicational layout as complete only when it has three main components: thought, which we express by speaking and being silent, because speech and muteness are integrated components of social communication, and also an additional component, normally accompanying those, which is intention. «Observation of this phenomenon convinces about its expanse, especially in our contemporary world. The strict connection of both components of the interface: speech and silence, appears on a very large area of social communication. It can be met in almost all, very diverse situations, beginning on intimate private contacts, ending on the world of great politics and international diplomacy» ${ }^{16}$.

Among 14 examples of double-layered communicational situation, such in which under the verbal text hidden is a deep area of silence, so the area of thoughts which is not revealed, Handke mentions advertisement as set only for speaking about pros of what it is supposed to recommend and dissembling cons and disadvantages of advertised goods.

\footnotetext{
${ }^{13}$ Jadacki, J. J. (2002), Pragmatyczne funkcje milczenia, Semantyka milczenia 2. Ed. K. Handke, p. 15-16.

${ }^{14}$ Jurkowski, M. (2002), Milczenie jako znak radiowy, Semantyka milczenia 2. Ed. K. Handke, p. 105-109.

${ }^{15}$ Górska, A. (2002), Strefa milczenia w interpretacji aktorskiej, Semantyka milczenia 2. Ed. K. Handke, p. 118.

${ }^{16}$ Handke, K. (2002), Milczymy mówiąc, Semantyka milczenia 2. Ed. K. Handke, p. 218.
} 
Other examples of double-layered communicational situation are e.g. collective, often loud prayer; court testimonies of witnesses, social convenance, political joke, confidential languages, opinions and reviews, public statements, language of diplomacy and politics. Conclusion coming out of Kwiryna Handke's deliberations refers to the contemporary reality, especially to the participation of media: «I previously emphasised, that the structure of double-layered communication is particularly widespread in our contemporary reality. It has a relation with the dimensions of lie and manipulation and lack of responsibility for words, therefore - in consequence with not believing words. To our newest times we owe the expression hidden agenda, which is something unclear and ambiguous. Common is a belief, that almost every hard, or even extraordinary issue must have a hidden agenda $\rangle^{17}$.

Katarzyna Szkaradnik in her article The Attempt to Express CommunicationalExistential Antinomies of Silence/Muteness refers to the first volume of Semantics of Muteness. Treating the rules of pragmatic linguistics and cognitivism as a basis, the author held very deep epistemology, existential and eschatology deliberations. She paid attention to important, in the view of communication, features and differences between silence and muteness:

1. Silence is a state of physical reality, while muteness is a result of action of communication participants, it is an effect of their will.

2. Silence itself is not a communicate, it is the muteness, which is expressive and meaningful because of the intentional refraining to speak.

3. Expression of silence can be an equivalent of speech in situations that overcome the communicational possibilities.

4. Muteness can be isolating (exposing subjectivism) or/and excluding as tool for controlling information flow, e.g. «media silence» ${ }^{18}$.

Despite the fact that in the publications presented here as source literature, the authors make theoretical (definitional) contradistinctions between silence and muteness, practically these lexemes are often used as equivalents. In the material basis collected for analysis in the project Communicational Potential of Silence, silence - always addressed to someone (one remains silent about something to someone) - treated following Jerzy Faryna as «communicational unit (made of silence/muteness) $\Downarrow^{19}$, muteness, in turn - according to the earlier presented Erling Kagge's philosophy - is a thing of a high value, luxurious and exclusive.

This assumptions were used in two authorial texts. First is a continuation of a dozen years of research on publicist work of Zygmunt Kałużyński, who according to Zdzisław Pietrasik, journalist and head of cultural section of «Polityka» weekly: «Was the most extraordinary Polish film critic. If he published in English language press, he surely would have gained international fame and appreciation $»^{20}$. Analyses of Kałużyński’s film criticism held from pragmalingustic and communicational perspective have already been published in a list of 15 authorial publications [i.a. 3, 4, 5, 6, 7, 8, 9], one of which is a scientific monograph $^{21}$. Zygmunt Kałużyński's work is an interesting and still inspiring material basis for multi-aspect research on possible usage of Polish language's lexical potential inn commu-

\footnotetext{
${ }^{17}$ Handke, K. (2002), Milczymy mówiąc, Semantyka milczenia 2. Ed. K. Handke, p. 221-222.

${ }^{18}$ Szkaradnik, K., Próba wysłowienia komunikacyjno-egzystencjalnych antynomii ciszy/milczenia, «Racjonalista. Kultura. Lingwistyka», URL: http://www.racjonalista.pl/kk.php/s,821

${ }^{19}$ Faryno, J., Skąd wiesz, kiedy milczę?, Semantyka milczenia. Zbiór studiów. Ed. K. Handke, p. 39.

${ }^{20}$ Pietrasik, Z. (2005), Widzieć jasno w ciemnościach, Kanon królewski. Jego 50 ulubionych filmów, p. 11.

${ }^{21}$ Filip, G. (2013), Mistrzowie gry na argumenty, Kałużyński, Treugutt, Bieńkowski, 280 p.
} 
nicational strategies. In Zygmunt Kałużyński's reviews the frequency of lexical units that directly represent the area of silence and muteness is not big. It does not mean though, that the critic does not use communicational potential of silence in his statements. As it results from the held analysis, for Zygmunt Kałużyński «Cinematography is above all a spectacle, a picture, one can't drag eyes off, working magically, while at the same time bringing some thought message $\rangle^{22}$. From the analysis of material basis comes a conviction, that in a perception of films, speaking shall leave space for watching. For convincing spectators to make such decision serve used by Kałużyński lexical units and constructions (in function of perlocutive mechanisms), which goal is influencing thoughts, behaviour, feelings of reviews' readers (potential spectators) and as a consequence convincing, that film shall be experienced in a subjective isolation (one of the mentioned functions of silence). Experiencing motion pictures should touch according to the critic, because this is in his opinion the role of a film. The spectators receive though a specific instruction for receipt and interpretation of films with paying attention to communicational possibilities of silence and muteness and above all, their expressive meaningfulness.

Advertisement communication being a part of branding strategy is one of social communication kinds and as such it was taken as a material basis for research on communicational potential of silence. In case of the authorial text called Communicational Potential of Silence. Automotive Brand Press the source of the material basis are automotive industry Polish-language quarterlies handed over for free to the clients registered in data bases of various brads' authorised services and occasionally given to a wider spectre of recipients while automotive exhibitions and fairs. Analysed periodics - issued by various concerns for brans Audi («Audi Magazine»), Peugeot («Peugeot Experience Magazine. Peugeot Brands' Magazine»), Subaru («Pleiads. Subaru’s Enthusiasts’ Magazine») and Volkswagen («Volskwagen Magazine», «Das Auto. Magazine») - from years 2012-2016. Because of their limited and elite distribution the material basis has though a niche character, whereas in view of the current tendencies in branding policy, analysis of such kind of press has a documenting function. Printed brand press as an information distribution channel was though replaced by e-branding, as an effect of what the concerns stopped issuing elite magazines for a hermetic circle of readers.

The usage of semantic field of silence in automotive press has a psychological explanation and it fits in the area of sensorial marketing, which goal is enhancing emotional relationship of clients with the brand by simultaneous stimulating a couple of senses. According to Katarzyna Stasiuk and Dominika Maison, the authors of Consumer's Psychology: «The development of sensorial marketing is connected with the fact, that advertising communication specialists, concentrated for a long time only on visual advertisement, began to search for new ways of reaching consumers by influencing their other senses: smell, taste, hearing, touch. Consumers are unaware of many of these influences; they feel actually, that in one clothing store the scent is really nice, but what they don't know, is that this scent was created and put there intentionally, they hear the music coming from the speakers in the store, but they don't know that its tempo and kind is not random. What is more, many consumers are not only unaware of such actions, but also of the influence which the scents, sounds or tastes can have on their behaviour and decisions $»^{23}$.

\footnotetext{
${ }^{22}$ Pietrasik, Z. (2005), Widzieć jasno w ciemnościach, Kanon królewski. Jego 50 ulubionych filmów, p.17.

${ }^{23}$ Stasiuk, K., Maison, D. (2014), Psychologia konsumenta, p. 99.
} 
Ending foreword to the second volume, Kwiryna Handke wrote: «In this convention though, an interdisciplinary discussion, which result are two volumes called «Semantics of Muteness», explicitly visible is the lack of works dedicated to «meaningful muteness» of press, TV and politicians. It is an open subject and we shall hope, that it will be held by our predecessors $\rangle^{24}$. The presented text, being an introduction to an individual research subject called Communicational Potential of Silence as well as two analytical publications described in it - with subtitles: Film Reviews and Automotive Brand Press - can be considered as a continuation of Kwiryna Handke's project, especially, as both texts are based on the example material coming from the source suggested by a Warsaw researcher - from press.

\section{REFERENCES}

1. Faryno, J., Skąd wiesz, kiedy milczę?, Semantyka milczenia. Zbiór studiów. Ed. K. Handke, p. 33-46.

2. Filip, G. (2013), Mistrzowie gry na argumenty, Kałużyński, Treugutt, Bieńkowski, $280 \mathrm{p}$.

3. Filip, G. (2014), Ways of Persuading Viewers to Erotic film on the Examples of Selected Journalistic Reviews, Żurnalistyka i kultura. Ed. E. N. Serdobintseva, p. 40-48.

4. Filip, G. (2015), "Syn kina czarnego» - semantyczne niuanse czerni w krytyce filmowej Zygmunta Kałuzyńskiego, Z badań nad językami europejskimi w aspekcie synchronicznym i diachronicznym, Księga jubileuszowa poświęcona Profesor Zofii Czapidze. Ed. E. Dźwierzyńska i D. Chudyk, p. 131-139.

5. Filip, G. (2016), Przykład jako argument w recenzjach filmowych, Médiá a text 5. Ed. M. Bočák, L. Regrutová, J. Rusnák, p. 61-69.

6. Filip, G. (2016), «Zbyt dorosłe dla dzieci i zbyt dziecinne dla dorosłych»-o przekonywaniu widza $\mathrm{w}$ recenzjach filmów komediowych, animowanych i przygodowych, Dziecko - literatura, sztuka, język. Ed. R. Starz, p. 290-299.

7. Filip, G. (2016), Słowiańska fantastyka jako przedmiot recenzji filmowych - uwagi pragmatyczne i językowe, Слов'янська фантастика, Збірник наукових пращь, т. 3, Ed. Деян Айдачич, p. 315-323.

8. Filip, G. Językowe wykładniki przekonywania widzów w recenzjach ekranizacji literatury XVIII i XIX wieku, Tradycja retoryczna w kulturze oświecenia i romantyzmu. Ed. A. Seweryn, M. J. Gondek, p. 311-326.

9. Filip, G. (2017), O historii i filmach historycznych w recenzjach Zygmunta Kałużyńskiego, Współczesne media-gatunki w mediach. Prace dedykowane Profesor Marii Wojtak, t. I, Zagadnienia teoretyczne. Gatunki w mediach drukowanych. Ed. I Hofman i D. Kępa-Figura, p. 377-391.

10. Górska, A. (2002), Strefa milczenia w interpretacji aktorskiej, Semantyka milczenia 2. Ed. K. Handke, p. 112-119.

11. Handke, K. (1999), Ed. Semantyka milczenia. Zbiór studiów, 254 p.

12. Handke, K. (2002), Ed. Semantyka milczenia 2, 229 p.

13. Handke, K. (2002), Milczymy mówiąc, Semantyka milczenia 2. Ed. K. Handke, p. 219222.

${ }^{24}$ Handke, K. (2002), Ed. Semantyka milczenia 2, p. 9. 
14. Jadacki, J. J. (2002), Pragmatyczne funkcje milczenia. Semantyka milczenia 2. Ed. K. Handke, p. 11-17.

15. Jurkowski, M. (2002), Milczenie jako znak radiowy, Semantyka milczenia 2. Ed. K. Handke, p. 105-109.

16. Kagge, E. (2017), Cisza. Opowieść o tym, dlaczego straciliśmy umiejętność przebywania w ciszy i jak ją odzyskać, $127 \mathrm{p}$.

17. Pietrasik, Z. (2005), Widzieć jasno w ciemnościach, Kanon królewski. Jego 50 ulubionych filmów, p. 11-17.

18. Pietura, A. (1999), Cisza w filmach Andrzeja Wajdy, Semantyka milczenia. Zbiór studiów, p. 203-225.

19. Stasiuk, K., Maison, D. (2014), Psychologia konsumenta, 458 p.

20. Szkaradnik, K., Próba wysłowienia komunikacyjno-egzystencjalnych antynomii ciszy/ milczenia, «Racjonalista. Kultura. Lingwistyka», URL: http://www.racjonalista.pl/ kk.php/s,821

21. URL: https://sjp.pwn.pl, dostęp 25 stycznia 2020 r.

\title{
СЕМАНТИКА МОВЧАННЯ ТА ТИШІ НА ОСНОВІ ПОЛЬСЬКИХ ГУМАНІТАРНИХ НАУК
}

\author{
Гражина Філіп \\ Жешувський університет \\ алея Рейтана, 16с, Жешув, Польщуа \\ e-mail: grazka.filip.@gmail.com \\ https://orcid.org/0000-0002-2564-1205
}

Стаття є вступом до окремого дослідницького проекту - Комунікативний потенціал тиші, - започаткованого у 2020 році. Його реалізація включає низку аналізів на основі різноманітних зразкових матеріалів. У тексті представлені, з одного боку, репрезентативні польські теоретичні та філософські дослідження щодо поняття та акту мовчання або антоніми мовлення / мовчання, а з іншого боку, аналіз цих концепцій у двох оригінальних публікаціях, заснованих на теоретичних засадах наукових праць таких дослідників, як: Квіріна Хандке, Сжи Фарина, Анна Пієтура, Яцек Юліуш Ядацький, Маріан Юрковський та спеціалізованих публікацій Олександри Гурської.

У комунікологічних та прагмалінгвістичних дослідженнях, згідно з твердженнями Сжи Фарини, мовчання трактується як «комунікативна одиниця (зроблена 3 тиші / мовчання)», а лексеми мовчання та тиші розглядаються як рівнозначні. Перша авторська стаття - «Комунікативний потенціал мовчання». Рецензії фільмів є продовженням майже десятирічного прагмалінгвістичного дослідження журналістських досягнень Зигмунта Калужинського. Предметом аналізу є комунікативні можливості мовчання для вПливу на читачів рецензій на фільми, наявність і частота його текстових постановок, а також лінгвістичні функції в антології, що представляє кінокритику Зигмунта Калжинського, «Королівський канон. Його 50 улюблених фільмів». Друга стаття - «Комунікативний потенціал тиші. Преса в автомобільній промисловості» - базується на філософських припущеннях Ерлінга Кагге: 1) тиша може бути доброзичливою та безпечною; 2) може бути самостійною цінністю, ексклюзивним та розкішним товаром. Рекламне спілкування, яке 
$€$ частиною стратегії брендування, - це один із видів соціальної комунікації, прийнятий як матеріальна основа в дослідженнях комунікаційного потенціалу мовчання. Джерелом зразкового матеріалу в цьому випадку є польські щоквартальні журнали автомобільної промисловості, які безкоштовно надаються клієнтам, зареєстрованим у базах даних авторизованих СТО різних марок автомобілів, іноді також доступні широкій аудиторії під час автомобільних виставок та ярмарків. Використання семантичного поля мовчання в галузевій автомобільній пресі має психологічне обгрунтування і потрапляє в сферу сенсорного маркетингу, метою якого є посилення емоційних стосунків споживачів з брендом, одночасно стимулюючи кілька органів чуття.

Ключові слова: прагмалінгвістика, семантика, мовчання, тиша, огляди фільмів, преса. 